\title{
The Legal Framework Limitations for the Effective Intergovernmental Relations in Tanzania
}

\author{
Rukia Mohamed Pazi \\ School of Public Administration and Management \\ Mzumbe University
}

Received: April 23, 2018 Accepted: May 24, 2018 Online published: June 13, 2018

doi:10.5296/jpag.v8i2.13278 URL: https://doi.org/10.5296/jpag.v8i2.13278

\begin{abstract}
Legal framework is very critical for the effective intergovernmental relations in Tanzania. It is through the legal framework where the spheres of the government derive their legitimacy and the manner of interaction. The study finds essential to have a glimpse on legal framework that provides for the existence of Intergovernmental relations in Tanzania. The intention is to have an assessment to see whether the legal framework in place provide a favorable environment for the central government and the local government authorities to work effectively. The study found out that the legal frame is ineffective to enhance central and local relations as it impinges the functionality of local government authorities. The study recommends that policy makers should consider enacting legal framework that clearly spell out the duties and demarcates the rights and responsibility of each party.
\end{abstract}

Keywords: legal framework, intergovernmental relations, constitution

\section{Introduction}

The effective intergovernmental relations depend on the legal framework. This is because the legal framework informs the operation of the spheres of the governments. More to that, it provides the division of powers among the spheres of the government and define their limits. It also assigns functions and responsibilities of the spheres as well as defining their boundaries. In this regards the paper aims at making an assessment on the existing legal framework to see if it facilitates effective operation of the central and local government. The paper is grounded on the following questions

a) Does the constitution inform the operation between the two governments?

b) Does the Constitution clearly define the boundaries or limits between central and local government to avoid interference? 
c) Since central and local government has shared responsibilities, does the constitution provide the mechanism for revenue sharing?

d) Does the constitution clearly define the function and responsibilities of central and local government?

In uncovering the mystery, the paper is critically assessing the constitution of United Republic of Tanzania as being the founder of Intergovernmental relations in mainland Tanzania. The paper employed secondary data whereby various documents such policies, reports, journal articles were explored to equip the study with relevant information regarding the legal framework and the functionality of central and local government.

The paper is divided into five areas as follows: Firstly, it discusses the meaning of intergovernmental relations. Secondly, the intergovernmental relations in Tanzania Mainland. Thirdly, the legal framework governing intergovernmental relations. Fourthly, the legal framework limitations and lastly, it gives recommends to improve intergovernmental relations.

\section{Meaning of Intergovernmental Relations}

There is no a uniform definition concerning intergovernmental relations. The underlying reason is the difference in the application of concepts from country to country. (Elazar 1987:16 cited in Shindane, 2011) argues that intergovernmental relations are to be found wherever two or more levels of the governments interact in the development and implementation of public policies and programmes. On the other hand Mollel (2010) is of the opinion that the interaction between different spheres in the government depending specifically on the size and the number of the spheres which is determined by the institutional arrangement of a certain country. In this case the structures of intergovernmental relations are mainly found in countries with federal systems such as Canada, Brazil, United States; as well as in countries with unitary characteristics such as Japan, South Africa, Tanzania, the United Kingdom etc (Shidane, 2011).

Generally, these scholars view IGR relative to interaction between different spheres of the government. Although this definition has been criticized by other scholars especially Anderson (1960) who posited that IGR is human being clothed with office who are real determiners of the relations among the units. Thus, the concept of IGR has to be designed based largely on human relations and human behavior. Anderson (1960) further postulated that there is no IGR, however, there are only relations among officials in different government unit whereby individual interaction among public officials is at core of IGR.

Other scholars view Intergovernmental relations in light to fiscal and administrative processes through which spheres of government share revenues and other resources normally associated with certain conditions that must be considered fulfill as a precondition to receiving assistance (Lyman, 2003). In a broad purview IGR is defined as the interaction of bilateral and multilateral. In addition to that the White Paper on Local Government in South Africa (1994) stipulates that Intergovernmental relations are set of numerous formal and informal process and institutional arrangements for multilateral and bilateral interaction 
within and among levels of the government. Furthermore, IGR is enlightened basing on the role played by all public officials include public officials in the government and representatives (politicians). With regard to the context of the discussion this paper defines intergovernmental relations as the interaction within and among spheres of the government.

\section{Intergovernmental Relations in Tanzania Mainland}

The intergovernmental relations in Tanzania exist to serve different purposes first; to provide for the arrangements that steer government accountability and foster citizen participation in the affairs of their government. Second to facilitate and promotes cooperative decision-making and formulation of policies that promote efficient service delivery to meet the needs of citizen. In this regard, Intergovernmental relations in Tanzania provide for the participation of two tiers government to attain the same. The first tire is the central government and the second tier is the local government. The central government composed of legislature and judiciary. Their power and functions are determined by the Constitution of United Republic of Tanzania of 1997. The article 63 and 64 bestows parliament with legislative power and declare the parliament as supreme law making body. The article 107 provides the judicial power to judiciary. The judiciary is the final decision maker in dispensation of justice. The ministries, executive agencies, commissions and public enterprises also belong to the central government tier. This tier extends to include Regions and Districts. The regions were established under article 61(1) which provides the establishment of Regional commissioners in each region. Regional Commissioners (RCs) and District Commissioners (DCs) are the principal representatives of the central Government within their regions and districts. They are vested with different responsibilities as detailed in the Regional Administration Act of 1997.

The second tier is the local government authorities. The local government authorities are instituted by the constitution of United Republic of Tanzania of 1997 under article 145 and 146. The constitution required the creation of local government authorities in every part of the country. The local governments are regarded as independent bodies with legal status. Local governments have also discretionary powers over local affairs within Republic of Tanzania. Thus, local governments are holistic having legal status (body corporate) functioning on the basis of specific and discretionary powers under the legal framework made by the national legislation (PMO-RALG, n.d). This means that local governments are legal entity, which can sue and be sued.).

\subsection{City}

The city council is the highest authority in urban local authorities in Tanzania. The establishment of the city council is made by the order of the president ${ }^{1}$. For the urban authority to qualify as a city should have a population of over 612,000 permanent residents (Warioba, 1999:71). The city council has the responsibility of co-coordinating the functions of the other local authorities within its jurisdiction. The city council is composed of

\footnotetext{
${ }^{1}$ Section 55 of the urban authorities Act No. 8 of 1982
} 
municipalities, which are within its jurisdiction ${ }^{2}$. For instance, the Dar es Salaam city council comprises of three municipalities namely, Ilala Municipal Council, Temeke Municipal Council and Kinondoni Municipal Council.

\subsection{Municipal}

The municipal council is the second level of urban authorities that is charged with power and functions to be exercised within the jurisdiction. In order for an area to qualify to be termed municipality it should have more than 80,000 permanent residents (Warioba, 1999).

\subsection{Town}

The town council is the lower authority to the municipal level. It has the same power and function as municipal council within their jurisdiction (Mzee, 2008). The only distinctions are the number of population within the area. The minimum qualification for the urban to become a town it should have the population of not more than 30, 001 permanent residents (Warioba, 1999).

\subsection{Ward}

The ward is an administrative area for overseeing the execution of council development projects, programmes and service delivery to the community. It also has a function of coordinating activities of villages, townships and neighborhoods within the ward (Mmari, 2005). The ward is considered as the electoral area for election of councilors representing the ward in the council. There is no elected council in the ward instead each ward has a development Committee (Mmari, 2005).

\subsection{Mtaa}

Mtaa (Neighbourhood), is the lowest level of local government in urban authorities (Kuusi, 2009). Mtaa has no executive or legislative power (Mzee, 2008) instead it exists to mobilize local participation. Every mtaa has the committee of not more than six members elected from amongst the residents of the $\mathrm{mtaa}^{3}$. The roles of $m t a a$ committees are to execute policies of the council, opining the council on the issues concerning development plans and activities of the mtaa, advising the Ward Development Committee on the issues relating to peace and security in the mtaa, keeping records of residents of the mtaa, and do such other things as may be conferred upon them by the Ward Development Committee (Kuusi, 2009)

\subsection{District Council}

District Authority is the highest authority of local government in rural parts of Tanzania. It is established by the Local Government (District authorities) Act No. 7 of 1982. The power to establish district council is conferred to minister responsible but after the consultation with the president ${ }^{4}$. The Act also establishes district councils, township authorities, wards

\footnotetext{
${ }^{2}$ Section 77 of urban authorities Act No. 8 of 1982

${ }^{3}$ Section 14A of the Urban Authorities Act, 1982

${ }^{4}$ Section 5(2) District Authority Act, 1982
} 


\section{Macrothink}

Journal of Public Administration and Governance

ISSN 2161-7104

2018, Vol. 8, No. 2

development committees, village councils and vitongoji (hamlets). District council has been given the mandate to authorize all by-laws from the village and township councils. It is also required by law to provide financial support to them ${ }^{5}$.

\subsection{Township Council}

Is the second level under district council. Township authority may be established by an order published in the government gazette by the minister responsible for local government. The condition for the township authorities to be established is that, it should have 500 households or a population of 9000 permanent residents in that area (Max, 1991). Township council has both executive $^{6}$ and legislative powers ${ }^{7}$.

\subsection{The Village}

The village government is the smallest local government unit in Tanzania (Mzee, 2008). The major organs of the village government are the village assembly and the village council. The village assembly is the utmost body at the village level. It is made up of any permanent member of the village above the age of eighteen ${ }^{8}$. It is responsible for general policy making in relation to the affairs of the village (Kuusi, 2009) as well as facilitating the election of the council members who will represent the villagers in the village council which is usually done for every five years. Village council is the executive and legislative organ of the village government ${ }^{9}$.

\subsection{Kitongoji (Hamlets)}

Kitongoji is the lowest local government organ in rural areas (Mzee, 2008). The law demands that the area of a village shall to be divided into not more than five vitongoji consisting of such number of households or of such geographical areas as may be determined by the village council and approved by the District Council ${ }^{10}$. Kitongoji does not have any legislative or decision-making powers ${ }^{11}$. It functions as a forum for mobilizing community participation (ibid).

\section{The Local Government Authorities in Mainland Tanzania}

The local government authorities in Tanzania are divided into two main parts; urban and rural. Urban authority covers the urban area of the country while rural authority covers the rural areas of the country. The existence of urban authorities is highlighted under Act No.8 of 1982 that stresses the creation of local government authorities in urban areas. The minister for local

\footnotetext{
${ }^{5}$ Local government finances Act no, 9 of 1982

${ }^{6}$ Section 136 of the District Act

${ }^{7}$ Section I60 of the District Act

${ }^{8}$ Section 55 of the District Act

${ }^{9}$ Section 56(1) (a)-)c) of the District Act

${ }^{10}$ Section 52 of the District Act

${ }^{11}$ Section $54 \mathrm{~A}$ of the District Act
} 
government has been empowered to institute urban authority or authorities in any area of Tanzania mainland ${ }^{12}$. The same Act establishes different kinds of urban authorities; commonly known as City Councils, Municipal Councils, Town Councils, Ward Development Committees and Mitaa $^{13}$

\section{Assessment of the Legal Framework Governing Intergovernmental Relations in Mainland Tanzania}

After the review of secondary data and assessment of the constitution it was found that, the constitution of Tanzania contains some malfunctions. The effective functionality of IGR in Tanzania is hindered by an array of malfunctions or reasons. Chiefly, the constitution does not spell out what type of central-local relationship should exist and inform operations of the two governments (ALAT, 2011). Since the constitution is the basis for IGR, one would expect a constitution to clearly show the division of power between central government and local government. Secondly, to clearly define the functions and responsibilities of central government and local government. Thirdly, to clearly define the limits of the power given to central government and the local government as well as defining their boundaries. However, all of these are not explicated in the constitution. Due to the aforementioned weaknesses the constitution does not guarantee local government protection from interference by the central government. More so, the constitution has given more power to the central government that creates a room for central hegemony. For instance, Article 145 (2) provides power to the parliament to enact law concerning the establishment of local government authorities, their structure as well as composition. In addition to that the constitution allows parliament to abolish local government authorities

Failure of the constitution to explicate the type of the central and local relationship has made it to be addressed in the Local government Reform programme (LGRP, 1998). Unfortunately, the relationship reflected in the Local government reform failed to provide a distinction between governance and administration. The local government authorities have two tires of governance. One tier starts from the higher level of local government authorities and the other from the lower level. The district council is an example of the governance body of the higher level. It consists of councilors who are elected by local people from each ward in the respective district. They are vested with supervisory role to district government executives, which is led by council director. Similarly, at lower level village council serves as governance tool of the village government (Kesale, 2017). The village council comprises of village chairperson and other members who are both elected by the people from sub-village. In this case, the two tires of the governance are required to be autonomous because they are made up of representative bodies of people (councilors) and given power to decide on matters, which affect the welfare of the people within their area of jurisdiction. On the contrary, they are subordinated to the central government and receive instructions, orders, guidelines that sometimes contravene with citizens priorities. In real sense, these two lower tiers are not

\footnotetext{
${ }^{12}$ Section 5 of the urban authorities Act No. 8 of 1982

${ }^{13}$ neighbourhoods
} 
supposed to be administratively subordinated to anybody although they are legally accountable. This contradiction occurs because of the failure of the constitution to define some central government roles. The central roles are defined in the local government reform programme such as supervisory, oversight, regulatory and auditing.

Another weakness is seen on the function of local government authorities. The constitution mentioned only the general functions that are to be discharged by the LGA's, which are stated in article 146(2) and failed to include the function of local government authorities. Instead it gives power to the parliament to enact laws, which can details the functions of local government authorities (Mzee, 2008). This resulted to the endowment of functions to be performed by local government authorities to be provided by the District and urban acts. The acts are said to contain nearly a hundred functions that local government authorities have to exercise. Moreover, local government authorities are not given authority to carry out any functions that are not stipulated in the any law or act (Warioba, 2009).

The power bestowed to the parliament to establish local government, resulted to the creation of local government system, which does not provide supervisory mechanism for one level to supervise the other. There is no hierarchical relationship with one level standing above the other. Each tier of the local government is created by its own law and performs its tasks based on that law. For instance rural and urban local government authorities are established through Acts No. 7 and 8 of 1982 while village councils are established by the Villages and Village Registration Act, No. 5 of 1975. Moreover, for instance the geographical and administrative boundaries put village councils under district councils and the two have equal relationship like that which exists between the central government and LGAs in general (ALAT, 2011). District Councils do not treat village councils as full governments and instead of relating to them on the basis of government-to-government, the latter is regarded as an administrative agent of the former (ibid).

Apart from that, the discharge of functions assigned to the local government authorities requires financial resources but the constitution does not provide the mechanism on how revenue between the two spheres should be shared. Instead it gives power to the parliament under article 146 (2) to enact law that provides for the local government revenue sources. The local government sources are explicated in the local government finance act of 1982 especially section 6,7 and 8. The revenue sources assigned to local are minor while central government has reserved itself the most important and elastic economy base in the economy. As a result it becomes so hard for local government authorities to have any substantial revenue source of their own (PMO-RALG, n.d).

In addition to that, the local government finance act does not provide a well-structured legal and regulatory framework for guiding administration of Local Government finances (Mzenzi, 2013). This is due to the fact that the Act contains numerous unclear, duplicative, and in some cases contradictory clauses (ibid). Which in turn, cause difficulties in revenues collection because it provides general conditions without stating the procedure to be used to collect that source of revenue.

Similarly, there have been interferences of the central government over the local government 
own sources of revenues. This is because the constitution has given power to central government to formulate policies that dictate the revenue generation of the local government authorities. In this regard, there have been numerous directives imposed to local government authorities. The directives are claimed to be responsible for the decline of the revenue raising ability in the local governments. For example, in the proposed budget of 2016/2017 the government has transferred the mandate of collecting property tax from the local government to Tanzania Revenue Authority (TRA), likewise in 2003 the government abolished development levy and local business licenses and permits (PMO-LARG, 2008). Morever, the CAG report of 2017 reported the issues of different directives from the executives and parliament that dictate how local government own sources ought to be used. In this case they may affect the ability of local government authorities to implement other activity on the priority list.

\section{Conclusion}

The paper examined the legal framework governing intergovernmental relation in Tanzania. It was found that the legal framework in place is ineffective to enhance central and local government relations. A lot of things are left unstated in the constitution including the division of responsibilities, limit of power, revenue sharing. In return, it hinders the functionality of local government authorities and also it provides the loopholes for the central control. The paper recommends that policy makers should consider enacting legal framework and the following should be explicated

- The legal framework should clearly define the limits of the power given to central government and the local government as well as defining their boundaries

- The type of central and local relation should be explicated

- Clear demarcation should be put between the functions that are supposed to be exercised by local government authorities and central government to avoid central government domination over the local government authorities' power

- The mechanism should be provided on how the revenue between the two spheres should be shared. Furthermore, a clear demarcation of the type or revenue for each government body in order to enhance public transparency and accountability.

\section{References}

Anderson, W. (1960). Intergovernmental relations in Review.University of Minnesta Press:Minneapolis.

Kesale, A. M. (2017). Selected Experiences of the Use of the Village Assembly in the Governance at the Grassroots Levels in Ludewa District Council in Tanzania. Public Administration and Governance, 7(2), 1-11. https://doi.org/10.5296/jpag.v7i2.11062

Kuusi, V. (2009). Aspects of Local-Self government ,Tanzania the associations of Finnish Local and Regional Authorities. 
Lyman, T. (2003). Intergovernmental relations and service delivery in South Africa. [Online] available:https://sarpn.org/documents/d0000875/docs/Layman,\%20Tim.pdf (February, 20, 2017).

Masue, O. (2014). Empowernment of School Committees and parents in Tanzania. Delienating Existance of Opportunity, Its use and Impact on school Decisions. Norway: University of Bergen.

Max. (1991). The Development of Local Government in Tanzania. Educational publisher\& Distributor :Dar es salaam

Mmari, D. (2005). Decentralization for service delivery in Tanzania.Norway: oslo

Mollel, H. (2010). Participation for Development: The reality of Decentralization in Tanzania. African Studies Centre:Leiden

Mzee, M. (2008). Local Government in Tanzania; Does the local government law in Tanzania give autonomy to local government ?University of Westen Cape.[ Online] available: http:/ etd.uwc.ac.za/xmlui/handle/11394/2568/(February 6, 2018)

Mzenzi, S. I. (2013). Revenue Mobilization Issues in Tanzanian Local Government Authorities, CKLnet Policy Brief No. 7: 2013

Prime Minister, Regional Administration and Local Government Authorities (PMO-RALG)(n.d.). History of Local Government in Tanzania. [Online] available:http://www.pmoralg.go.tz/.../history/HISTORY\%20OF\%20LOCAL\%20GOVE over 100http ( Sept 1, 2013).

Reddy, P. (2001). Intergovernmental Relations in South Africa. Politeia. 20(1). 21-39.

Republic of South Africa. (1994). White Paper of Local Government.[online] available: https://www.cogta.gov.za/cgta_2016/wp-content/.../whitepaper_on_Local-Gov_1998.pdf (January 1, 2017).

Shidane, J. (2011). To what extent could the intergovernmental relations enhance the gradual effective realisation of socio economic rights?. A focus an access to housing and water.

The Association of Local Government Authorities in Tanzania (ALAT) (2011). The state of local democracy and good local governance in Tanzania.[online] available: http:// www.clgf.org.uk/...The_State_of_Local_Democracy_and_Good_Local_Governance

(January, 1, 2017)

The Local Government (District Authorities) Act No 7 of 1982

The Local Government (Urban Authorities) Act No 7 of 1982

The United Republic of Tanzania. (1975). The village registration Act NO.5.

United Republic of Tanzania. (1998). Policy Paper on Local Government Reform Programme. Dar Es Salaam: PMO-RALG.

United Republic of Tanzania (PMO-RALG) (2008). Local government reform programme implementation report: 1998-2008. Dodoma: PMO-RALG.

United Republic of Tanzania. (1982). Local Government Act. Government Printers: Dar eSal aam.

United Republic of Tanzania. (1982). Local Government Finances Act no 9 . 


\section{Macrothink}

Journal of Public Administration and Governance ISSN 2161-7104 2018, Vol. 8, No. 2

United Republic of Tanzania. (1977). Constitution of United Republic of Tanzania. Government Printers: Dar es Salaam

Warioba, M. (1999). Management of local government in Tanzania; Some Historical Trends.Institute of Development Studie: Mzumbe.

\section{Copyright Disclaimer}

Copyright for this article is retained by the author(s), with first publication rights granted to the journal.

This is an open-access article distributed under the terms and conditions of the Creative Commons Attribution license (http://creativecommons.org/licenses/by/4.0/). 